\title{
RARA Gene Translocation
}

National Cancer Institute

\section{Source}

National Cancer Institute. RARA Gene Translocation. NCI Thesaurus. Code C156350.

A cytogenetic abnormality that refers to any translocation involving the RARA gene. 